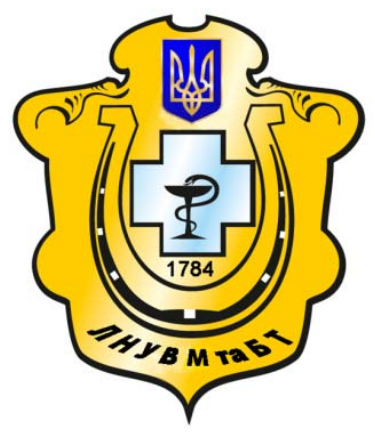

Науковий вісник Львівського національного університету ветеринарної медицини та біотехнологій імені С.3. Гжицького

Scientific Messenger of Lviv National University of Veterinary Medicine and Biotechnologies named after S.Z. Gzhytskyj

doi:10.15421/nvlvet7314

ISSN 2518-7554 print

ISSN 2518-1327 online

$\underline{\text { http://nvlvet.com.ua/ }}$

УДК 619:636.1.2.3.4:616.9:579:577

\title{
Визначення поліморфних варіантів фрагментів ДНК збудників хламідій- них інфекцій сільськогосподарських тварин
}

\author{
М.В. Корнієнко ${ }^{1}$, І.М. Ксьонз ${ }^{2}$ \\ marina-korniienko@mail.ru, igor.ksyonz@ukr.net \\ ${ }^{1}$ Національний науковий цеентр «Інститут експериментальної $і$ клінічної ветеринарної медицини» \\ вул. Пушкінська, 83, м. Харків, 61023, Україна; \\ ${ }^{2}$ Інститут свинарства та агропромислового виробництва НААН, \\ вул. Шведська Могила, 1, м. Полтава, 36013, Україна
}

\begin{abstract}
Проведено біоінформачійні дослідження 411 первинних нуклеотидних послідовностей ДНК чотирьох збудників хламідійних інфекиій сільськогосподарських тварин (Chlamydia abortus, Chlamydia pecorum, Chlamydia pneumoniae ma Chlamydia suis) отриманих із міжнародних електронних баз даних «GenBank» та «РиbMed». Метою досліджень було проведення біоінформачійного вирівнювання нуклеотидних послідовностей різних генів для визначення поліморфних ділянок ДНК бактерій роду Chlamydia, які викликають захворювання у великої та дрібної рогатої худоби, коней та свиней, що є базовими для конструювання олігонуклеотидних праймерів молекулярно-генетичних тест-систем здатних диференціювати означені збудники за видами. При цььому визначено, що найвищий рівень варіабельності, який складає 97, 1\%, має ген, щңо кодує основний мембранний білок хламідій (МОМР). Методом вирівнювання первинних послідовностей означеного гену, за допомогою комп'ютерних програм «MEGA4» та «MEGA7», визначено поліморфні фрагменти нуклеотидних послідовностей ДНК C. abortus, C. pecorum, C. pпеитопіеа та C. suis. Перевірку специфічності поліморфних фрагментів, визначених для кожного із чотирьох видів хламідій з нуклеотидними послідовностями мікроорганізмів як умовно патогенних, так $i$ збудників інших інфекиій, проводили за допомогою комп'ютерної онлайн-програми «Blast». Поліморфні фрагменти гену, щңо кодує МОМР означених бактерій роду Chlaтуdia будуть використані при розробленні дизайну олігонуклеотидних праймерів тест-систем для індикаиії $і$ видової диференияіації збудників хламідійних інфекиій сільськогосподарських тварин у полімеразній ланцюговій реакції.

Ключові слова: сільськогосподарські тварини, хламідійна інфекиія, електронні бази даних, нуклеотидні послідовності, поліморфні фрагменти, $16 \mathrm{~S}$ rRNA, RNase P RNA, MOMP.
\end{abstract}

\section{Определение полиморфных вариантов фрагментов ДНК возбудителей хламидийных инфекций сельскохозяйственных животных}

\author{
М.В. Корниенко ${ }^{1}$, И.Н. Ксёнз ${ }^{2}$ \\ marina-korniienko@mail.ru, igor.ksyonz@ukr.net
${ }^{1}$ Национальный научный иенттр «Институт экспериментальной и клинической ветеринарной медициньл», ул. Пушкинская, 83, г. Харьков, 61023, Украина;
${ }^{2}$ Институт свиноводства и агропромылиленного производства НААН, ул. Шведская Могила, 1, г. Полтава, 36013, Украина

Проведены биоинформационные исследования 411 первичных нуклеотидных последовательностей ДНК четырех возбудителей хламидийных инфекиий сельскохозяйственных животных (Chlamydia abortus, Chlamydia pecorum, Chlamydia pneumoniae и Chlamydia suis), полученных из международных электронных баз данных «GenBank» и «PubMed». Целью исс-

\section{Citation:}

Korniyenko, M.V., Ksyonz, I.M. (2017). Definition of DNA fragments polymorphic variants of chlamydial infections pathogens in farm animals. Scientific Messenger LNUVMBT named after S.Z. Gzhytskyj, 19(73), 66-70. 
ледований было проведение биоинформачионного выравнивания нуклеотидных последовательностей различных генов для определения полиморфных участков ДНК бактерий рода Chlamydia, вызываюших заболевания у крупного и мелкого рогатого скота, лошадей и свиней, которые являются базовыми для конструирования олигонуклеотидных праймеров молекулярно-генетических тест-систем, способных дифференцировать указанные возбудители по видам. При этом определено, что самый высокий уровень вариабельности, который составляет 97,1\%, имеет ген, кодирующий основной мембранный белок хламидий (МОМР). Методом выравнивания первичных последовательностей указанного гена, с помощью компьютерных программ «MEGA4» и «MEGA7», определены полиморфные фрагменть нуклеотидных последовательностей ДНК С. abortus, C. pecorum, C. pпеитопіеа и C. suis. Проверку специфичности полиморфных фрагментов, определенных для каждого из четырех видов хламидий к нуклеотидным последовательностям микроорганизмов, как условно-патогенных, так и возбудителей других инфекций, проводили с помощьюю компьютерной онлайн-программы «Blast». Полиморфные фрагментьл гена, кодирующего МОМР указанных бактерий рода Chlamydia будут использованы при разработке дизайна олигонуклеотидных праймеров тест-систем для индикации и видовой дифференцииции возбудителей хламидийньх инфекиий сельскохозяйственных животных в полимеразной цуепной реакции.

Ключевые слова: сельскохозяйственные животные, хламидийная инфекиия, электронные базы данных, нуклеотидные последовательности, полиморфные фрагменты, $16 \mathrm{~S}$ rRNA, RNase P RNA, MOMP.

\title{
Definition of DNA fragments polymorphic variants of chlamydial infections pathogens in farm animals
}

\author{
M.V. Korniyenko ${ }^{1}$, I.M. Ksyonz ${ }^{2}$ \\ marina-korniienko@mail.ru, igor.ksyonz@ukr.net \\ ${ }^{I}$ National Scientific Center «Institute of Experimental and Clinical Veterinary Medicine», \\ Pushkinska Str., 83, Kharkiv, 61023, Ukraine; \\ ${ }^{2}$ Institute of Pig Breeding and Agroindustrial Production NAAS, \\ Shvedska Mohyla Str., 1, Poltava, 36013, Ukraine
}

Under the currently existing classification, adopted at the Second European Symposium «Animal Chlamydioses and Zoonotic Implications (EMAC-2)», Chlamydia pathogens of animals and humans are intracellular gram-negative bacteria belonging to Chlamydiales order, Chlamydiaseae family, Chlamydia genus. The above mentioned genus includes 11 species: C. abortus, C. avium, C. caviae, C.felis, C. gallinacea, S. muridarum, C. pecorum, C. pneumoniae, C. psittaci, C. suis and C. trachomatis, 10 of them being pathogenic for animals and Chlamydia trachomatis being exclusively human Chlamydiosis agent. Development of highly sensitive and specific molecular genetic test systems for indication and species differentiation of the said Chlamydia genus bacteria will permit to reliably study various aspects of chlamydial infection.

Aim of the study was to perform bioinformatic alignment of different genes' nucleotide sequences to determine polymorphic DNA regions of Chlamydia genus bacteria, which are the basis for designing oligonucleotide primers for molecular genetic test systems capable of differentiating pathogens, causing disease in cattle and small ruminants, horses and pigs, by species.

Bioinformatic study has been performed in 411 primary nucleotide DNA sequences of genes encoding $16 S$ rRNA, RNase P RNA and MOMP of four chlamydial infections agents of farm animals (C. abortus, C. pecorum, C. pneumoniea, C. suis) obtained from the international electronic databases «GenBank» and «PubMed». Meanwhile, it was determined that the gene encoding the main outer membrane protein (MOMP) of Chlamydia possesses the highest variability level, making $97.1 \%$. Using the method of aligning the primary sequences of the said gene, by means of «MEGA4» and «MEGA7» software, polymorphic fragments of nucleotide DNA sequences have been determined for C. abortus, C. pecorum, C. pneumoniea and C. suis.

Specificity testing of polymorphic fragments, determined for each of the four chlamydia species with nucleotide sequences of microorganisms, both opportunistic and other infections pathogens, was carried out using «Blast» online software applications. Polymorphic fragments of the gene encoding MOMP of the above Chlamydia genus bacteria will be used to design oligonucleotide primers of test systems for indication and specific differentiation of farm animals' chlamydial infections agents in polymerase chain reaction.

Key words: farm animals, chlamydial infection, electronic databases, nucleotide sequences, polymorphic fragments, MOMP.

\section{Вступ}

Хламідіози є групою інфекційних захворювань ссавців і птахів, що мають широке розповсюдження в усьому світі та Україні зокрема. За існуючою на сьогодні класифікацією, прийнятою на II Європейському симпозіумі «Animal Chlamydioses and Zoonotic Smplications (ЕМAC-2)», збудники хламідіозів тварин і людини є внутрішньоклітинними грамнегативними бактеріями порядку Chlamydiales, родини Chlamydiaceae, роду Chlamydia. До означеного роду входить 11 видів: C. abortus, C. avium, C. caviae, C.felis, C. gallinacea, C. muridarum, C.pecorum, C. pneumoniae, C. psittaci, C. suis та C. trachomatis, $10_{3}$ яких $є$ патогенними для тварин, а Chlamydia trachomatis винятково збудником хламідіозу людини (Sachse, 2013).

Хламідії викликають гострі, а частіше хронічні або латентні інфекції, що вражають різні органи і системи, маючи урогенітальні, респіраторні, ентеральні, суглобові, неврологічні, офтальмологічні, а також генералізовані клінічні прояви (Lobzyn et al., 2003; Ksyonz et al., 2014).

До бактерій роду Chlamydia, що викликають захворювання великої та дрібної рогатої худоби, коней і свиней, належать такі види, як C. abortus, C. pecorum, C. pneumoniea та C. suis. 
Chlamydia abortus - збудник, найбільш розповсюджений серед жуйних та свиней, вражає переважно плаценту. Chlamydia pecorum є збудником захворювань тварин, найчастіше великої та рогатої худоби, свиней, коней і собак, який вражає нервову систему, респіраторний і шлунково-кишковий тракти (Manankov et al., 1995). Chlamydia pneumoniae розглядається в основному як респіраторний збудник, що найчастіше викликає гострі та хронічні бронхіти і пневмонії (Gaydos, 2001; Liuba et al., 2003; Pospisil and Canderle, 2004; Baker et al., 2007). Цей вид хламідій має три біовари: TWAR, Koala та Equine (назви яких пов'язані 3 джерелом виділення штамів - від людей, коал і коней) (Grayston et al., 1995; Barbarova, 2002; Belotserkovskaya and Synopalnykov, 2008). Chlamydia suis вперше була виявлена у свиней (Sus scrofa). Найчастіше цей вид хламідій викликає у тварин кон'юнктивіти, ентерити та пневмонії (Schautteet et al., 2010).

Розроблення високочутливих та специфічних молекулярно-генетичних тест-систем для індикації видової диференціації бактерій роду Chlamydia, патогенних для сільськогосподарських тварин, надасть можливість достовірно вивчати ті чи інші аспекти хламідійних інфекцій.

Метою $і$ завданням досліджень було проведення біоінформаційного дослідження нуклеотидних послідовностей різних генів для визначення поліморфних ділянок ДНК бактерій роду Chlamydia, які викликають захворювання у великої та дрібної рогатої худоби, коней та свиней, що слугуватимуть для створення ПЛР-тест-систем, здатних диференціювати означені збудники за видами. Для досягнення поставленої мети потрібно було розв'язати такі завдання: провести вирівнювання отриманих 3 міжнародних баз даних нуклеотидних послідовностей генів, що кодують $16 \mathrm{~S}$ rRNA, RNase P RNA i MOMP бактерій C. abortus, C. pecorum, C.pneumoniea та C. suis 3 визначенням рівня їх гомології; вирівняти фрагменти послідовностей кожного гену усіх чотирьох збудників між собою, визначивши найбільш варіабельний за нуклеотидними послідовностями ген; визначити локуси, що мають місце винятково в геномі кожного із означених видів хламідій і не є гомологічними для геномних структур інших мікроорганізмів, зокрема й інших видів бактерій порядку Chlamydiales.

\section{Матеріал та методи досліджень}

Матеріал та методи досліджень даної роботи грунтуються на біоінформаційних дослідженнях 411 первинних нуклеотидних послідовностей бактерій роду Chlamydia, a came C.abortus, C.pecorum, C. pneumoniea та C. suis, отриманих із міжнародних баз даних «GenBank» та «PubMed».

Вирівнювання нуклеотидних послідовностей на наявність поліморфних ділянок для гібридизації, характерних для того чи іншого виду бактерій роду Chlamydia, проводили з використанням комп'ютерних програм «MEGA4» та «MEGA7» (Tamura et al., 2007).

Перевірку специфічності поліморфних фрагментів, визначених для кожного із чотирьох видів хламідій 3 нуклеотидними послідовностями мікроорганізмів як умовно патогенних, так і збудників інших інфекцій, проводили за допомогою онлайн-програми «Blast».

\section{Результати та їх обговорення}

Проаналізовано 411 нуклеотидних послідовностей ДНК бактерій роду Chlamydia, що викликають хламідіози серед сільськогосподарських тварин, зокрема: Chlamydia abortus - 44 (16S rRNA - 23, RNase P RNA - 6, MOMP - 15), що складає 10,7\% від загальної кількості проаналізованих нуклеотидних послідовностей; Chlamydia pecorum - 118 (16S rRNA - 21, RNase P RNA - 3, MOMP - 94), що складає 28,7\%; Chlamydia pneumoniea - 45 (16S rRNA - 35, RNase P RNA - 1; MOMP - 9), що складає 10,9\% та Chlamydia suis - 204 (16S rRNA - 34, RNase P RNA - 1, MOMP - 169), що складає 49,6\%.

Вирівнюванням 23 первинних нуклеотидних послідовностей гену, що кодує $16 \mathrm{~S}$ rRNA, за кодами доступу: АВ001783, АВ001816, AF451289, AF451292, AF451294, AF451295, CPU61766, CPU68444CPU68446, CPU76710, D85709, EF486853-EF486856, EF486857, NR_036834, NR_074950, NR_111993, Z49871, Z49872; 6 первинних послідовностей гену, що кодує RNase P RNA, за кодами доступу: AJ012170, DQ257291-DQ257295 та 15 нуклеотидних послідовностей гену, що кодує основний білок зовнішньої мембрани МОМР, за кодами доступу: AF269256, AF272945, CHTOMPAAD, CHTOMPAAAA, DQ227703, DQ478954, DQ471955, EF202609, EU086705, EU515131, EU531729, JQ312426, KC879303, KF130872, KP984478, Chlamydia abortus, встановлено, що рівень гомології становить 99,8\% для 16S rRNA i RNase P RNA та 99,5\% для MOMP, тобто варіабельність послідовностей не перевищує 0,2$0,5 \%$.

Вирівнюванням 21 первинних нуклеотидних послідовностей гену, що кодує $16 \mathrm{~S}$ rRNA, за кодами доступу: CPU73785, CPU737822, AB001777, AB001776, AB001775, AB001774, NR_121750, NR_027576, CPU68439, CPU68435, CP्PU68432, CPU68431, HQ457466, HQ457465, EU684929, AY055109, D85717, D85716, D85715, NR_102975, NR_115658; 3 первинних послідовностей гену, що кодує RNase P RNA, за кодами доступу: АJ012170 АJ131089-AJ131091 та 94 нуклеотидних послідовностей гену, що кодує МОМР, за кодами доступу: AF269279, АB512082, АB512077, EU350137, EU350138, GQ228166, GQ228169, GQ228183, GQ228185, GQ228192, GQ228194, GQ228196, HQ457484, HQ457492, HQ457493, JX272924, JF309281, JF309283-JF309286, JF309288JF309291，JF309293-JF309295，JN016880，JN594066, JN594068, JN594085-JN594122, JX311945-JX311952, KF150132-KF150137, KF150139-KF150141, LC021417-LC021422, ORF663, Chlamydia pecorum, встановлено, що рівень гомології становить 97,3\% для $16 \mathrm{~S}$ rRNA, 99,5\% для RNase P RNA та 53,1\% для MOMP, тобто варіабельність нуклеотидних послідовностей генів 16S rRNA та RNase P RNA не перевищує 0,5-2,7\%, а для гену, що кодує MOМР цього виду збудника, рівень варіабельності відповідає 46,9\%. 
Вирівнюванням 35 первинних нуклеотидних послідовностей гену, що кодує $16 \mathrm{~S}$ rRNA, за кодами доступу: AF100957, AF139200, AF347606, AF347610, AF451290, AF451293, AY026521, AY026522, AY555075, CHT16SR, CPU68421-CPU68426, CPU73783, CPU76711, DQ444323, FJ236984, GQ507433-GQ507442, HQ232478, HQ232479, NR_026527, NR_074981, Z49873, Z49874 та 9 нуклеотидних послідовностей гену, що кодує основний білок зовнішньої мембрани МОМР, за кодами доступу: KJ541750-KJ541758, Chlamydia pneumoniae, встановлено, що рівень гомології становить 94,6\% для $16 \mathrm{~S}$ rRNA та 79,1\% для МОМР, а варіабельність відповідно 5,4\% та 20,9\%. Первинна послідовність гену, що кодує RNase P RNA (код доступу - AJ012174) C. pneumoniae, не підлягала вирівнюванню, оскільки є єдиною в доступних генетичних базах.

Вирівнюванням 34 первинних нуклеотидних послідовностей гену, що кодує $16 \mathrm{~S}$ rRNA, за кодами доступу: АВ283006-АВ283019, АВ284054, AF481047, AY013477, AY661794-AY661796, AY661797AY686473, CTU68420, CTU68427-CTU68429, CTU73110, DQ118376, NR_029196 та 169 нуклеотидних послідовностей гену, що кодує MOMP, за кодами доступу: АВ270720, АВ270722-АВ270724, АВ270736, AB270737, AB270739-AB270743, AJ004876AJ004880, AJ005616, AJ440241, AF269270-AF269278, AY601751, AY601752, AY687630-AY687639, CHTOMPAAM, DQ118378, KP165539, U82956, U82958-U82960, Chlamydia suis, встановлено, що рівень гомології становить 97,3\% для 16S rRNA та $51,8 \%$ для МОМР, тобто варіабельність нуклеотидних послідовностей гену $16 \mathrm{~S}$ rRNA становить 2,7\%, а MOMР - 48,2\%. Первинна послідовність гену, що кодує RNase P RNA (код доступу - AJ012176) C. suis, не підлягала вирівнюванню, оскільки є єдиною в доступних генетичних базах.

При вирівнюванні первинних послідовностей гену, що кодує $16 \mathrm{~S}$ rRNA C.abortus, C.pecorum, C. pneumoniea та C. suis поміж собою, виявлено рівень гомології 84,4\%. Рівень варіабельності відповідно складає $15,6 \%$.

При вирівнюванні первинних послідовностей гену, що кодує RNase P RNA чотирьох означених видів хламідій поміж собою, виявлено рівень гомології 94,5\%. Рівень варіабельності відповідно складає 5,5\%.

При вирівнюванні первинних послідовностей гену, що кодує MOMP C. abortus, C. pecorum, C. pneumoniea та C. suis поміж собою, виявлено рівень гомології 2,9\%. Рівень варіабельності відповідно складає 97,1\%.

Такі результати свідчать про те, що нуклеотидні послідовності генів 16S rRNA та RNase P RNA є малопридатними для конструювання олігонуклеотидних праймерів тест-систем, призначених для видової диференціації хламідій. Однак при створенні молекулярно-генетичних тест-систем для індикації збудників хламідіозів на рівні роду, нуклеотидним послідовностям цих генів слід надавати пріоритет.

Ген, що кодує МОМР бактерій роду Chlamydia, завдяки високому рівню поліморфізму нуклеотидних послідовностей, є найбільш придатним для конструю- вання праймерів, що фланкуватимуть фрагменти ДНК, специфічні для кожного із видів збудників хламідіозів сільськогосподарських тварин.

Визначено значну кількість фрагментів ДНК гену, що кодує MOMР бактерій роду Chlamydia патогенних для сільськогосподарських тварин, що є специфічними винятково для C.abortus, C.pecorum C. pneumoniea та C. suis.

\section{Висновки}

Біоінформаційними дослідженнями 411 секвенованих нуклеотидних послідовностей різних генів Chlamydia abortus, Chlamydia pecorum, Chlamydia pneumoniea та Chlamydia suis, отриманих із світових генетичних баз, встановлено, що найвищу варіабельність, 97,1\%, має ген, що кодує МОМР хламідій, та найвищий рівень гомології - 84,4\% та 94,5 мають гени, що кодують 16S rRNA i RNase P RNA.

Визначені поліморфні фрагменти гену, що кодує МОМР збудників хламідійних інфекцій сільськогосподарських тварин, можуть бути використані при розробленні дизайну олігонуклеотидних праймерів молекулярно-генетичних тест-систем для індикації і видової диференціації бактерій C. abortus, C. pecorum, C. pneumoniea та C. suis.

Перспективою подальших досліджень є використання результатів вирівнювання нуклеотидних послідовностей гену MOMP бактерій C.abortus, C. pecorum, C.pneumoniea та C. suis у розробленні діагностичних засобів для їхньої індикації і видової диференціації у будь-якому хламідієвмісному матеріалі. Чітка видова диференціація матиме вирішальне значення як у наукових дослідженнях різних ізолятів та штамів хламідій, так і у виробленні стратегії оздоровчих заходів у певному неблагополучному щодо хламідіозу об'єкті тваринництва.

\section{Бібліографічні посилання}

Barbarova, L.A. (2002). Khlamydyoz loshadey: épyzootolohyya dyahnostyka y mery borby: dyss. ... kand.. vet. nauk.: 16.00.03. Barbarova Lyubov Andreevna. Kazan, 167 (in Russian).

Belotserkovskaya, Y.H., Synopalnykov, A.Y. (2008). Rol Chlamydia pneumoniae v bronkholehochnoy patolohyy cheloveka. Klyn. mykrobyol. antymykrob khymyoter. 10(1), 24-33 (in Russian).

Ksyonz, I.M., Skrypnyk, V.H., Nekhoroshykh, Z. M. (2014). Zoonozni khlamidiozy: [monohrafiya]. - K., DNDILDVSE (in Russian).

Lobzyn, Yu.V., Lyashenko, Yu.Y., Poznyak, A.L. (2003). Khlamydyynye ynfektsyy. SPb.: OOO «Yzdatelstvo FOLYANT» (in Russian).

Manankov, V.V., Tykhonov, N.H., Rybkyna, R.A. (1995). Khlamydyozy y smeshannye ynfektsyy u selskokhozyaystvennykh zhyvotnykh. Aktualnye probl. veterynaryy. Barnaul. 93 (in Russian).

Liuba, P., Pesonen, E., Paakkari, I. (2003). Acute Chlamydia pneumoniae infection causes coronary endothelial dysfunction in pigs. Atherosclerosis. 167(2), 215222 . 
Gaydos, C.A. (2001). Chlamydia pneumoniae and its proposed link to multiple sclerosis: To be or not to be? Neurology. 56, 1126-1127.

Baker, G.A., Tremple, N., Katz, J. (2007). Chlamydial infections causing pneumonia in piglets. Clin. Microbiol. Infect. 8, 14-21.

Grayston, T.J., Kuo, C.C., Coulson, A.S. (1995). Chlamydia pneumoniae (TWAR) in Atherosclerosis off the Carotid Artery. Circulacion. 92(2), 3397-3400.

Pospisil, L., Canderle, J. (2004). Chlamydia (Chlamydophila) pneumoniae in animals: a review. Vet. Med. Czech. 49, 129-134.

Schautteet, K., Beeckman, D.S., Delava, P., Vanrompay, D. (2010). Possible pathogenic interplay between
Chlamydia suis, Chlamydophila abortus and PCV-2 on a pig production farm. Vet. Rec. 166(11), 329-333.

Sachse, K. (2013). Neues aus dem NRL Chlamydiose. Sekond European Meeting on [ «Animal Chlamydioses and Zoonotic Implications (EMAC-2)»], (Germany, Jena, 13-14 june 2013), Friedrich Loffler Institut, 9596.

Tamura, K., Dudley, J., Nei, M., Kumar, S. (2007). MEGA4: Molecular Evolutionary Genetics Analysis (MEGA) software version 4.0. Molecular Biology and Evolution. 10, 1093.

Стаття надійшла до редакиії 1.03.2017 